\title{
C113 有機強誘電体を用いたカテーテル型触営センサの改良 Improvement of catheter tactile sensor composed of organic ferroelectrics
}

\author{
○黒田 大介（九エ大） \\ 正竹中 慎（香川産技セ，九エ大） \\ 正 高嶋一登（九工大， \\ 堀江 聡 (神戸大) \\ 石田 謙司（神戸大）
}

Daisuke KURODA, Kyushu Institute of Technology, 2-4 Hibikino, Wakamastu, Kitakyushu

Kazuto TAKASHIMA, Kyushu Institute of Technology

Makoto TAKENAKA, Kagawa Prefectural Industrial Technology Center

Toshiharu MUKAI, RIKEN

Satoshi HORIE, Kobe University

Kenji ISHIDA, Kobe University

Key words :Tactile Sensor, Organic Ferroelectrics, PVDF Film, Palpation, Piezoresponse, Catheter

\section{1. 粕吾}

近年, 脳梗塞や動脈瘤, 狭心症などの血管内治療において は, カテーテルやガイドワイヤを用いることで患部の切開を 最小限に抑える低侵襲手術が普及している.しかし，これら の機器を屈曲した管内の深部まで挿入することは非常に難 しく, 術者に高度な技術と熟練が要求される。こういった背 景から, 血管壁との接触力測定による手術の操作性・安全性 の向上や, 生体組織表面の剛性測定による病変部の検出など に応用可能な触覚センサの開発が望まれている.

そこで, 我々はポリフッ化ビニリデン (PVDF) やVDF才 リゴマーなどの有機強誘電体を用いたカテーテル型触覚セ ンサを試作している(1) (3).これらの有機強誘電体は $\mathrm{CH}_{2} \mathrm{CF}_{2}$ を繰り返し構造として持ち, 高分子材料ならではの特性とし

て以下に示す利点がある.

（1）軽量かつ柔軟である.

(2) 圧電定数が大きい.

（3）共振が鋭くなく広範囲の周波数に応答する.

(4) 鉛を含有しない.

（5）加わった応力の絶対值ではなく, 微分值を出力する.

これまでの研究 ${ }^{(1)}$ において, PVDF フィルムを一枚用い たカテーテル型触覚センサを試作し, センサ先端に錘を落下 させる実験や実体血管モデルへの挿入実験を行った.これら の実験により, 錘の力積の増加に伴うセンサ出力の増加や, 血管形状に対応したセンサの出力が得られることが確認で きた. しかし，センサの感度が高い力の方向が一方向に限ら れるなどの課題もあった. そこで, 本研究ではPVDFフィル ムを二枚用いた, 二方向の力に対しても安定した出力值が得 られるカテーテル型触覚センサを試作し, 錘の落下実験によ り試作品の出力特性の評価を行った.

\section{2. 实験}

\subsection{PVDF を用いた触賞センサの試作}

本研究で試作した触覚センサの外観を Fig.1 に, 試作手順 を Fig.2 に示す. まず，母体となるシリコンゴム（信越化学 工業, KE-106）を自作した型により試作し, シリコンゴム上 にプラスチックフィルム (厚み : $0.22 \mathrm{~mm}$ ), PVDF フィルム

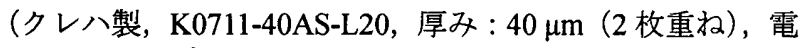
極面積 : $48 \mathrm{~mm}^{2}$ ) を弾性接着剤により接着した (Fig.2 (a)). また,フィルム電極は導電性接着剤を用いてシールド付可動 信号ケーブル（外径 : $5.2 \mathrm{~mm}$ ) に接続した. 次に, Fig.2 (a) で作製したものを $90^{\circ}$ 回転させて型にはめこみ，もう一枚 の PVDF フィルムを貼り付けるシリコンゴム母体を作製し
た（Fig.2（b)). 次に, 二方向の力を検出するためにもう一 枚の PVDF フィルムをフィルムどうしが直交するように貼 り付けた（Fig.2（c)）。最後に PVDF フィルム, シールド付 可動信号ケーブルをシリコンゴムでカバーし完成となる (Fig.2 (d)).この時ケーブルのもう一端は BNC 端子を接続 し, 電流電圧変換アンプ $\left(10^{8} \mathrm{~V} / \mathrm{A}\right)$ を経てオシロスコープ に接続した，センサ出力はセンサ先端が曲げられ，センサ中 立面に対して PVDF フィルムが伸長されることで得られる. また, センサの出力電流は加わった応力（またはひずみ）の 微分に比例する.

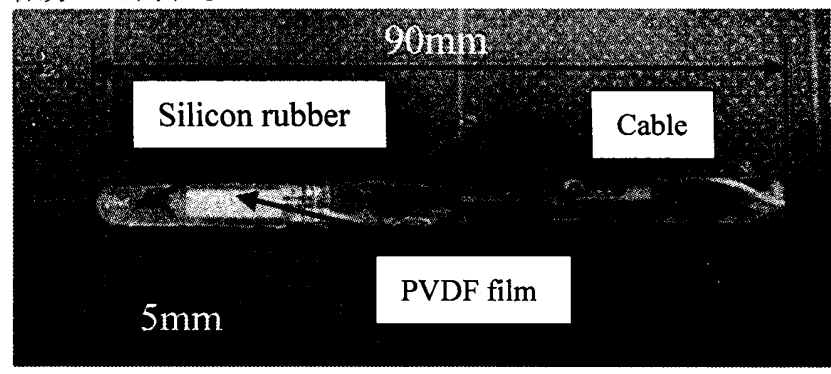

Fig.1 Prototype of catheter tactile sensor

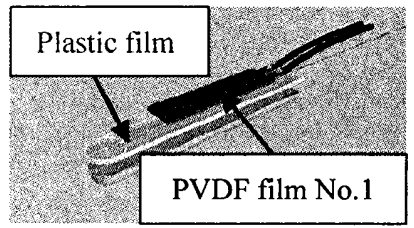

(a)

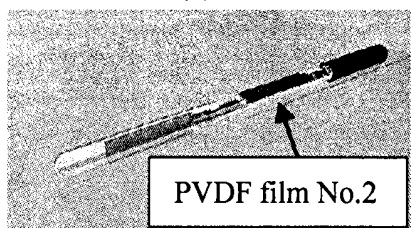

(c)

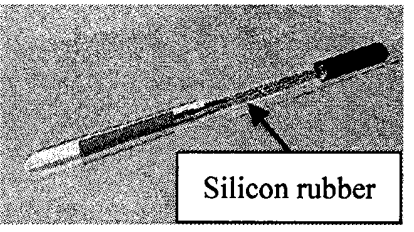

(b)

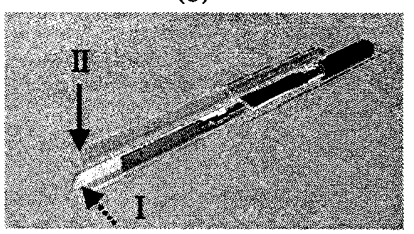

(d)
Fig.2 Fabrication process of catheter tactile sensor

\section{2 锺を用いた实験}

試作した触覚センサの根元を治具で固定し, 片持ち梁状の 触覚センサの先端に錘（0.89 g) を自由落下させ, 錘がセン サ先端に接触した際の出力值を測定した. 一方，センサ先端 の変位はレーザ変位計により測定した。錘は初期高さ $5 \mathrm{~mm}$ 
から $25 \mathrm{~mm}$ の高さまで $5 \mathrm{~mm}$ 刻みで変化させ, 各高さにおい て 5 回ずつ実験を行った。また，錘は Fig.2（d）に示す I, II の方向から落下させ, 出力值の評価を行った.

\section{3.结果及び考宽 \\ 3.1 周波数解析}

今回の実験によって得られたセンサ先端の変位の周波数 解析結果を Fig.3 に, センサ出力値の周波数解析結果を Fig.4 に示す.なお Fig.3, Fig.4 は共に $5 \mathrm{~mm}$ の高さの錘を Fig.2(d) の I 方向から落下させた際の周波数解析結果を示している. Fig.3, Fig.4から, 錘の落下によって $20 \mathrm{~Hz}$ 以下の周波数で センサの先端が変形し, さらに同様の周波数で出力值が得ら れていることがわかる．また Fig.4より， $60 \mathrm{~Hz}$ や $180 \mathrm{~Hz}$ 付 近の周波数域でもピークを示すことが確認できた。この 60 $\mathrm{Hz}$ 付近のピークは電源ノイズによるものであり，180 Hz 付 近のピークは錘の接触によりセンサに生じた不規則な縦振 動によるものと考えられる. 以上のことから，今回の実験に よって得られた出力値について $20 \mathrm{~Hz}$ のローパスフィルタを 行い, 鍾の力積とローパスフィルタ後の振幅値の関係を評価 した.

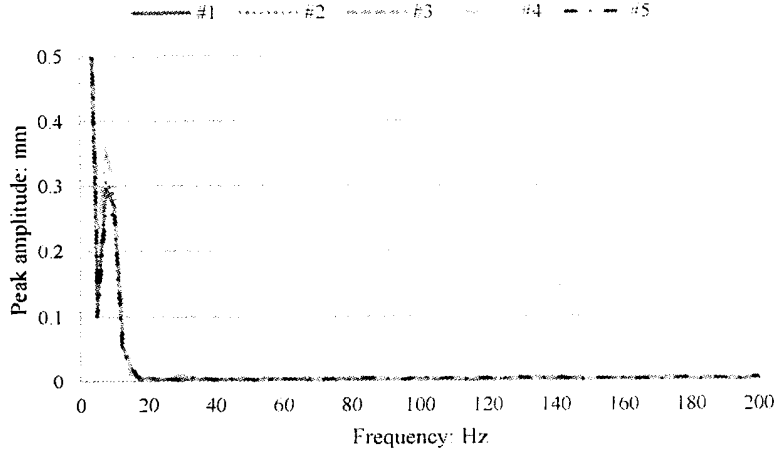

Fig.3 Frequency analysis result of displacement

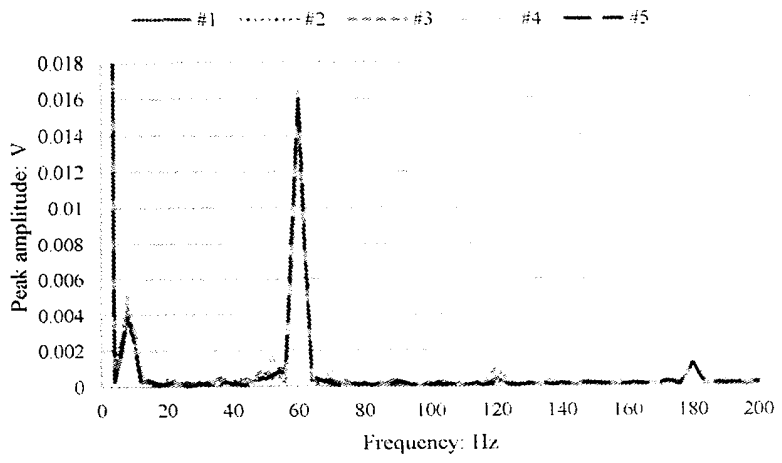

Fig.4 Frequency analysis of the output (PVDF film No.1)

\section{2 ローパスフィルタ結果}

今回の実験によって得られた出力値について, $20 \mathrm{~Hz}$ の口 一パスフィルタを行った際の出力例を Fig.5 に示す.なお Fig.5 は $5 \mathrm{~mm}$ の高さの錘を Fig.2（d）の I 方向から落下させ た際の結果を示している．また，それぞれの錘の落下方向

（Fig.2（d） I， II）における錘の力積と最大振幅值との関 係を Fig.6に示す。この時の最大振幅値とは，各錘高さにお ける 5 回分の最大振幅值 (Fig.5 中矢印(1)）の平均としてい る. Fig.5より，錘が最小高さであっても，センサの振動に 対応した出力值が得られていることが確認できた. Fig.6よ り，錘の力積の増加に伴う最大振幅值の増加が確認できた. また PVDF フィルム面の伸長方向の違いにより最大振幅值
には差が生じ，錘の力積が同じであっても，PVDFフィルム が大きく曲げられる場合の方が最大振幅值は大きくなるこ とが確認できた. 一方で, PVDF film No.1-Пの場合のみ, 最 大振幅値の増加が確認できなかった。これは, PVDFフィル 厶面に対して錘の接触方向が不規則であったため, PVDF フ イルム面の伸長方向もまた不規則であったためだと考えら れる。

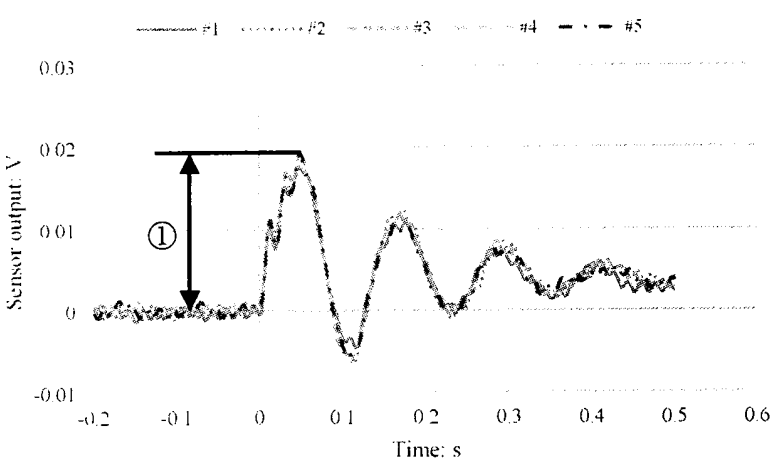

Fig.5 Example of filtered sensor signal (PVDF film No.1)

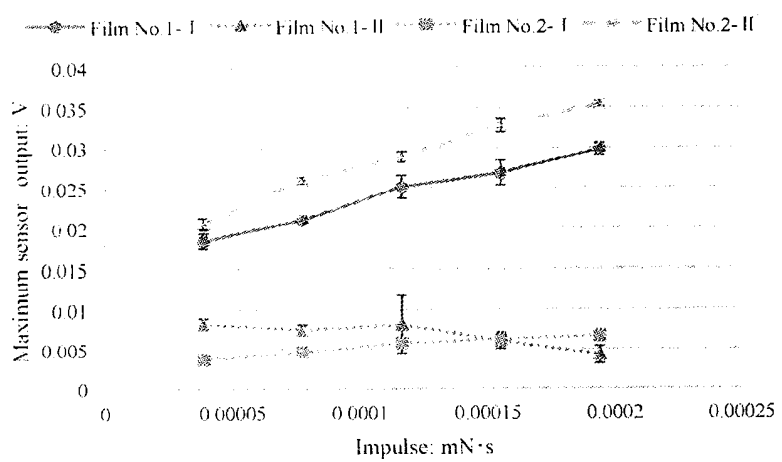

Fig.6 Relationship between maximum sensor output and impulse of weight

\section{4. 結司}

本研究では, PVDF フィルムを二枚用いた柔軟なカテーテ ル型触覚センサを試作し, 錘の落下実験により二方向の力を 測定できることが確認できた. 今後はさらに多方向の力に対 しても安定した出力值が得られるセンサの開発や, 他の有機 強誘電体である $\mathrm{P}(\mathrm{VDF} / \mathrm{TrFE})$ や VDF オリゴマーを用いてセ ンサの小型化を図る必要がある．また，実体血管モデルへの 挿入実験等を行い, 表面形状とセンサ出力值の関係について の評価を行いたい.

期辞

本研究は競輪の補助（26-126）を受けて実施しました.

\section{多考文献}

（1）黒田大介, 高嶋一登, 竹中慎, 向井利春, 堀江聡, 石 田謙司, 上田裕清, “有機強誘電体を用いたカテーテル 型触覚センサの試作”，第 26 回バイオエンジニアリン グ講演会講演論文集, pp. $55 \sim 56$

（2）高嶋一登, 堀江聡, 向井利春, 石田謙司, 松重和美, “触覚センサのための VDF オリゴマーの圧電特性”, 日本ロボット学会誌, Vol.26, No.6 (2008), pp.711〜 717

（3）高嶋一登, 竹中慎, 向井利春, “有機強誘電体触覚セン サを用いた生体内触診の数值解析”, 日本ロボット学会 誌, Vol.30, No.2 (2012), pp.195 204 